\title{
Apprenticeships: Bringing College to the Workplace
}

\author{
Siobhan Magner \\ Apprenticeship, Traineeship and Work Based Learning Unit \\ Education and Training Boards \\ Dublin, Ireland \\ Naomi Jackson \\ CCT College \\ Dublin, Ireland
}

(C) Siobhan Magner and Naomi Jackson. This work is licensed under the Creative Commons Attribution-NonCommercial-ShareAlike 4.0 International License. To view a copy of this license, visit https://creativecommons.org/licenses/by-nc-sa/4.0/.

\begin{abstract}
"Across Europe apprenticeships are acknowledged as vital elements in the economic regeneration of member states. That is most true in an Irish context where we need to substantially enhance the range of apprenticeships. Apprenticeships address crucial skill shortages across many sectors of the economy. What is particularly noteworthy about new apprenticeships is that there is no "glass ceiling" in these learning pathways as some are the equivalent of master's degrees or doctorates. The continued expansion of apprenticeships into new areas of the economy will enhance their image and profile and are a real option to academic-only learning pathways." (Moriarty, 2018)
\end{abstract}

Research suggests that one in six third-level learners are dropping out of their college courses during their first year (Higher Education Authority (HEA), 2017, cited in O'Brien, 2017). The European People's Party claim statistics show that one in 5 young people in Europe under the age of 24 is currently not in education, employment or training (Maydell, 2015); a contributory factor to the recent reinvigoration of apprenticeships as a model of education.

Following a review of Apprenticeships, commissioned by Ruairi Quinn T.D, and Minister for Education and Skills, the new apprenticeship model emerged in Ireland. The new apprenticeship, or post 2016 apprenticeship, is no longer a mid-level skillsbased, craft training programme but a work-based learning programme in a wide range of disciplines leading to awards from level 5 to level 10 on the National Framework for Qualifications.

In November 2014, the Apprenticeship Council was established, with the objective of expanding apprenticeships into new sectors to benefit employers and employees (Apprenticeship Council, 2016). The Council comprises representatives from industry, the Irish Congress of Trade Unions, further and higher education and training bodies and the Department of Education and Skills. SOLAS has responsibility for apprenticeships on behalf of the government. The Department of Education, the Higher Education Authority, Quality and Qualifications Ireland, Education and Training 
Boards Ireland (ETBI), industry and further and higher education providers are also key stakeholders and work in close collaboration with SOLAS.

The Department of Education and Skills provides funding to education providers via the HEA for higher education apprenticeships and via SOLAS for further education and training apprenticeships. SOLAS maintains the register of approved employers and the national register of apprentices. ETBI is the national representative association for Ireland's sixteen Education and Training Boards (ETBs). Its Apprenticeship, Traineeship and Work-Based Learning Unit was established to deliver sectoral enhancement projects and initiatives, including Apprenticeship programmes within the ETBs and further education sector. QQI has published Statutory Quality Assurance Guidelines for Apprenticeships (Quality and Qualifications Ireland, 2016), for education providers and is also an awarding body for apprenticeships. This paper summarises the current position pertaining to post-2016 apprenticeships in Ireland in relation to design, challenges and benefits.

Generation Apprenticeship is a major expansion project introduced by SOLAS, the key role of which is to double the number of learners from diverse backgrounds pursuing the apprenticeship route (Department of Education and Skills, 2016). Ireland now has apprenticeship programmes in construction, engineering, hospitality, electrical, accounting, insurance, motor and ICT, auctioneering and property services, craft butchery, and Original Equipment Manufacturing, all being delivered in a range of further education and higher education institutions. The first Level 9 apprenticeship programmes were approved for development by the Apprenticeship Council in 2017 in the spheres of accounting, engineering, animation and lean sigma. University of Limerick is currently developing a Level 10 Professional Doctorate apprenticeship in Principal Engineering, the first of its kind in Ireland (Department of Education and Skills, 2017). By 2020 the goal is that there will be 30,000 people engaged in 70 different types of apprenticeships (SOLAS, 2018).

The post 2016 apprenticeships are programmes which formally combine and alternate learning in the workplace with learning in an education and training centre. They have specific defining characteristics:

- Prepare the apprentice for a specific occupation

- Lead to a nationally recognised qualification on the NFQ at level 5 or above

- Have a minimum duration of two years

- Provide a minimum of $50 \%$ learning in the workplace;

- Apprentices must be employed under a contract of apprenticeship for the programme duration (Apprenticeships, 2017).

New apprenticeships are industry-led. The Consortium Steering Group (CSG), comprising of employers, professional bodies, occupation regulators, along with the education providers is central to the apprenticeship programme development, management and ongoing fitness-for-purpose of the programme for the occupation (Quality and Qualifications Ireland, 2016, p.43). The apprenticeship model exemplifies academic-enterprise partnerships enriching education and the employability of 
graduates through employer-led curriculum design and employment focused programme delivery and assessment. This provides an opportunity for education institutions to support the development of industry networks and to increase Ireland's economic competitiveness through business-led innovative education, as envisaged by the Hunt Report (Department of Education and Skills, 2011, pp. 75-76).

Research indicates that employers face challenges when participating in apprenticeship programmes. Rowe et al. (2017) in their study of managing degree level apprentices in the workplace, found that recruiting the right candidate; supporting apprentices through a degree whilst working full time; and the amount of time the apprentice spends off the job are the key challenges facing businesses. They make a number of recommendations to counteract these challenges including the need for effective employer-led recruitment processes; rigorous retention strategies and employer involvement and board-level motivators including the establishment of mentoring programmes to ensure that benefits are experienced by the organisation. They also highlight the need for a genuine employer-driven pedagogic approach to help overcome the challenge of apprentices being required to spend so much time off the job.

Research published by Mulkeen et al. (2017) suggest that academic providers need to support the apprentice by making learning materials available in a variety of formats as apprentices work across various industries and at different times.

Kenyon (2005) identified the delivery of the knowledge skills, and competences required in the workplace as one of the key benefits of apprenticeships. This continues to be the driving motivator for employer engagement. In November 2016, the US Department of Commerce (2016, p.8) undertook a study of apprenticeship employers to establish the benefits to business. They found that the need for skilled workers was cited as the most common factor for companies engaging in apprenticeships.

Evidence shows that in those European countries where the apprenticeship system is most developed young people have increased employability options compared to other countries who do not offer apprenticeship programmes (European Commission, 2013). For example, approximately 60 per cent of Germany's youth participate in workbased learning programmes whereby further education providers educate these apprentices during the off-the-job component. Employers pay for most of the training as well as apprentices' wages. In December 2017, the unemployment rate for 15-24year olds in Germany was 6.7 per cent, compared to 17.3 per cent across EU member states (OECD, 2018).

New apprenticeships in Ireland are industry driven and as such are putting the employer in the driving seat of programme development. Researched published in April 2018 by The National Apprenticeship Service in the UK suggests the following benefits to employers:

Employers can -

1. Nurture learner interest in a career within their company 
2. Assist potential employees in relation to understanding the education and skills required to secure jobs

3. Enhance their reputation in their communities as supporters of education and providers of good jobs

4. Form stronger partnerships with local schools and help ensure that the curriculum is supporting the development of essential 21st century skills required to succeed in the workplace

5. Provide employees with valuable opportunities to serve as ambassadors for the company and to hone their public speaking, communications, and leadership skills

6. Improve employee retention by boosting employees' job satisfaction and sense of purpose

The 2017 UK Department for Education research report on employers' evaluation of apprenticeships suggests

- $96 \%$ of employers with apprentices have experienced at least one benefit from taking on apprentices, and most can count at least 8 benefits

- $74 \%$ of employers say that apprentices improved products or service quality, and $78 \%$ say that they improved productivity. Apprentices become highly skilled even before they finish their training.

- $69 \%$ of employers say that employing apprentices improved staff retention. $65 \%$ of apprentices stay working for the company that trained them when they complete their apprenticeship.

- Most apprenticeships generate a net overall benefit to the employer within a few years.

Apprenticeships provide an opportunity to widen participation. The apprentice can embark on a professional career in those sectors such as accounting or insurance; sectors that were previously only accessed through professional exams or academic higher education programmes. A similar outcome is evident in the United States. A recent report published by the Department of Commerce $(2016$, p. 1) highlighted that apprenticeships are now expanding beyond the traditional trade and construction areas into new industries and are also providing access to women and minorities.

The earn and learn education model pays the apprenticeship a salary throughout the duration of the programme whilst the programme is free. Apprentices are fully supported in the workplace by experienced employees who coach, mentor and guide them as well as affording them the opportunity to gain the knowledge, skills and competencies required to work in that specific occupation.

From an apprentice's perspective, by participating on work-based learning programmes they gain valuable work experience that can launch their careers. They interact with and learn from their mentors and other employees as well as gain an understanding of workplace norms. Most importantly they become work ready by connecting what they are learning in the classroom to the education and skills required for success in today's work environment. 


\section{References}

Apprenticeships (2017) 'Developing a National Apprenticeship Handbook'. Higher Education Authority. Available at: http://hea.ie/assets/uploads/2017/06/Developing-a-NationalApprenticeship-Handbook.pdf (Accessed: November 1, 2018).

Apprenticeship Council (2016) 'About Apprenticeships'. Available at:

http://www.apprenticeship.ie/en/about/Pages/About.aspx?anchor=Council (Accessed:

November 1, 2018)

Department of Commerce (2016) The benefits and cost of apprenticeship: A business perspective'. Department of Commerce. Available at:

https://www.commerce.gov/sites/commerce.gov/files/migrated/reports/the-benefits-andcosts-of-apprenticeships-a-business-perspective.pdf (Accessed: November 1, 2018).

Department for Education (2017) 'Apprenticeships evaluation 2017: employers - Research report November 2017'. Department for Education. Available at:

https://assets.publishing.service.gov.uk/government/uploads/system/uploads/attachment da ta/file/659710/Apprenticeships evaluation 2017 employers.pdf (Accessed: November 1, 2018).

Department of Education and Skills (2016) 'Action plan to expand apprenticeship and traineeship in Ireland 2016-2020'. Department of Education and Skills. Available at: http://www.solas.ie/SolasPdfLibrary/ActionPlanDec16.pdf (Accessed: November 1, 2018).

Department of Education and Skills (2017) 'Ministers Bruton \& Halligan announce 26 new apprenticeships'. Available at: https://www.education.ie/en/Press-Events/PressReleases/2017-Press-Releases/PR17-12-08.html (Accessed: November 1, 2018).

Department of Education and Skills (2011) 'National Strategy for Higher Education to 2030 Report of the Strategy Group'. Department of Education and Skills. Available at: http://hea.ie/assets/uploads/2017/06/National-Strategy-for-Higher-Education-2030.pdf (Accessed: November 1, 2018).

European Commission (2013) 'The effectiveness and costs-benefits of apprenticeships: Results of the quantitative analysis'. European Commission. Available at: http://ec.europa.eu/social/BlobServlet?docld=11352\&langld=en (Accessed: November 1, 2018).

Kenyon, R. (2005) 'The business benefits of apprenticeships: the English employers' perspective', Education Training, 47(4/5), pp. 366-373.

Maydell, E. (2015) 'Jobs for young people - a vision that works', EPP Group in the European Parliament. The Group of the European People's Party. Available at: http://www.eppgroup.eu/news/Jobs-for-young-people---a-vision-that-works (Accessed: November 1, 2018). 
Moriarty, M. (2018) ETBI Welcomes Announcement of New Apprenticeships [Press Release]. Available at: https://www.etbi.ie/etbi-welcomes-announcement-of-newapprenticeships/ (Accessed: 15 November 2018).

Mulkeen, J., Abdou, H. A., Leigh, J. and Ward, P. (2017) 'Degree and Higher Level Apprenticeships: An Empirical Investigation of Stakeholder Perceptions of Challenges and Opportunities', Studies in Higher Education.

National Apprenticeship Service (2018) 'Achieving the benefits of apprenticeships - A guide for employers'. National Apprenticeship Service. Available at:

https://assets.publishing.service.gov.uk/government/uploads/system/uploads/attachment da ta/file/716634/Apps A5 Achieving the benefits.pdf (Accessed: November 1, 2018).

O'Brien, C. (2017) 'More than 6,000 students drop out of college in first year', The Irish Times, 27 April. Available at: https://www.irishtimes.com/news/education/more-than-6-000students-drop-out-of-college-in-first-year-1.3062362 (Accessed: 13 November 2018).

OECD (2018) 'Unemployment - Youth unemployment rate - OECD Data'. OECD. Available at: https://data.oecd.org/unemp/youth-unemployment-rate.htm (Accessed: November 1, 2018).

Quality and Qualifications Ireland (2016) 'Apprenticeship programmes - statutory quality assurance guidelines, apprenticeship programmes - statutory quality assurance guidelines'. QQI. Available at: https://www.qqi.ie/Publications/Publications/Apprenticeship Programmes QAG Topic-Specific.pdf (Accessed: November 1, 2018).

Rowe, L., Moss, D., Moore, N. and Perrin, D. (2017) 'The challenges of managing degree apprentices in the workplace', Journal of Work-Applied Management, 9(2), pp. 185-199.

SOLAS (2018) 'Let an apprenticeship drive your career to new heights', The Irish Times, 12 September. Available at: https://www.irishtimes.com/sponsored/solas/let-an-apprenticeshipdrive-your-career-to-new-heights-1.3616976 (Accessed: 14 November 2018). 